\title{
Georg von Neumayer and geomagnetic research
}

\author{
W. Schröder ${ }^{1}$, K.-H. Wiederkehr ${ }^{2}$, and K. Schlegel ${ }^{3}$ \\ ${ }^{1}$ Geophysical Commission, Hechelstraße 8, 28777 Bremen, Germany \\ ${ }^{2}$ Institut für Geschichte der Naturwissenschaften, Universität Hamburg, 20146 Hamburg, Germany \\ ${ }^{3}$ Copernicus Gesellschaft e.V., Bahnhofsallee 1a, 37081 Göttingen, Germany
}

Received: 8 September 2010 - Revised: 14 November 2010 - Accepted: 30 November 2010

- Published: 22 December 2010

\begin{abstract}
Neumayer was a prominent figure in the development of geophysics in the 19th century from a scientific as well as from an organisational point of view. In this paper we review and highlight his activities and efforts in geomagnetic research within five different aspects of geomagnetism: regional geomagnetic surveys, geomagnetic work in German naval observatories, geomagnetic investigations during the First Polar Year 1882/83, modifications of the Gaussian theory, and geomagnetic charts. In each field Neumayer was a researcher, a thinker, and a stimulating coordinator.
\end{abstract}

\section{Introduction: Neumayer's path to geomagnetism}

Georg Balthasar Neumayer (Fig. 1, for a brief CV, see Priesner, 1999) was born on 21 June 1826 in Kirchheimbolanden, Rheinpfalz (Lower Palatinate) which belonged to the Kingdom of Bavaria at that time. After attending local schools he studied at the Polytechnikum in Munich where he graduated 1849 as civil engineer. Afterwards he worked as an assistant at the University of Munich and for half a year at the Sternwarte (the astronomical observatory) in Bogenhausen (near Munich) under Johann von Lamont (1805-1879). The latter, one of the leading geomagneticians of that time, introduced Neumayer to this field. In his book "Auf zum Südpol!" ("Forward to the South Pole") Neumayer wrote later (Neumayer, 1901a, p. 3):

"Bald nach Vollendung meiner Studien und nach Ablegung meines Examens (1849) wurde in mir der Gedanke rege, meine wissenschaftliche Kraft der Forschung auf dem Gebiete des Erdmagntismus zu widmen". ("Soon after having finished my university studies and after my graduation (1849) the idea arose to dedicate my scientific force to the investigation of geomagnetism").

He realized that geomagnetic measurements in the south polar region in particular, are sparse and therefore impor-

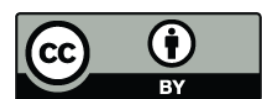

Correspondence to: $\mathrm{K}$. Schlegel

(kristian.schlegel@copernicus.org) tant, and simultaneously that nautical science, navigation, and astronomy would be a necessary tool for him, to work in this field and to improve the knowledge about geomagnetism (Neumayer, 1901a). In order to gain some experience in this respect, Neumayer signed on a German merchant ship as an ordinary seaman for a voyage to South America (1850/51). After his return he studied nautical sciences at the "Seefahrtschule" (the nautical academy) in Hamburg and passed the mate's examination in 1851. During a second trip, this time to Australia (1852-1854), he undertook an expedition to the interior of this country, dug for gold, and already started geomagnetic measurements. He returned to Germany with the decision to set up an observatory for navigation, meteorology, and terrestrial magnetism in Australia. In his efforts to get funds, he was supported by Alexander von Humboldt (1769-1859) whom he visited in Berlin and successfully convinced this eminent scientist with his scientific plans (Wiederkehr and Schröder, 1989). With further help of Justus von Liebig (1803-1873), the scientific advisor of Maximilian II, King of Bavaria, he secured royal funds and founded the "Flagstaff" observatory (named after a hill near Melbourne) in 1857. After this observatory was taken over by the colonial government in 1859, Neumayer became its official Director and Vice President of the Royal Society of Victoria, and stayed in Australia until 1864 (Neumayer, 1901a). More details about this period of Neumayer's life are published elsewhere (Kretzer, 1984; Krause, 2005). 


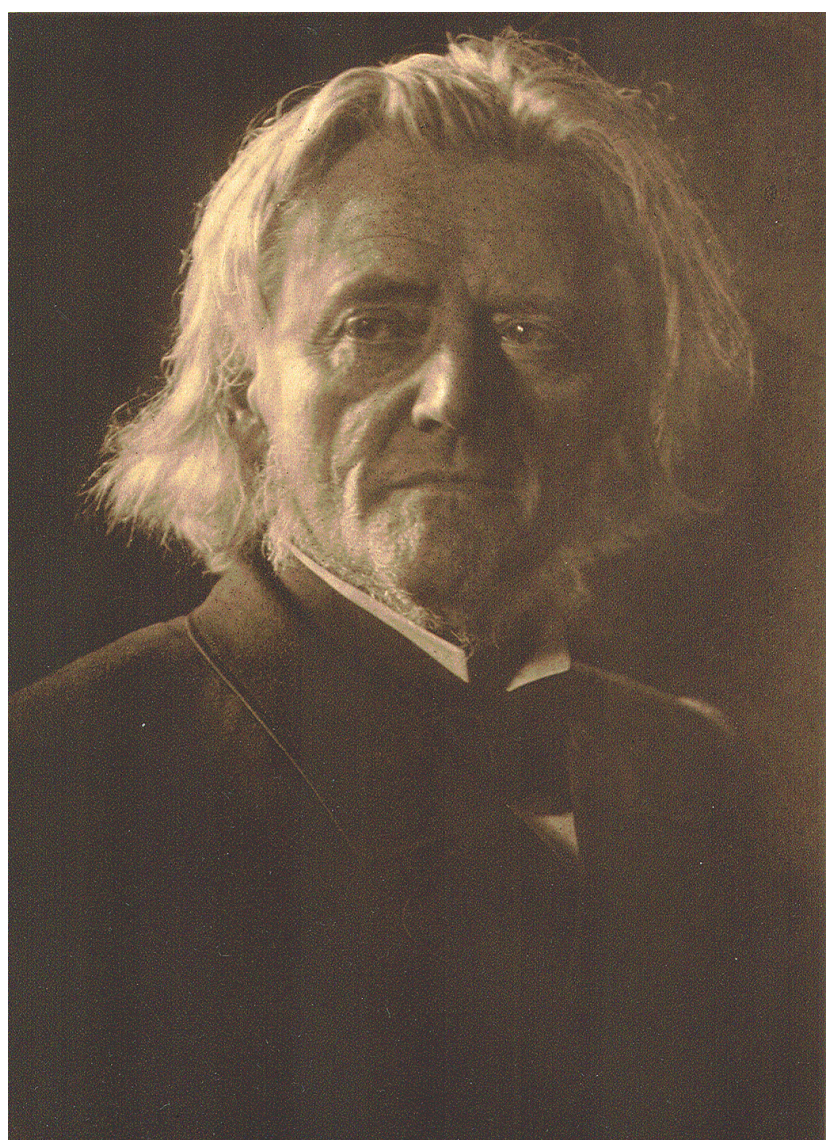

Figure 1. Georg von Neumayer, 1905, photograph of Rudolf Dührkoop (reproduced from WIKIMEDIA COMMONS, http:// commons.wikimedia.org).

\section{Geomagnetic regional surveys}

His first geomagnetic survey Neumayer already performed in 1855 , it was a regional magnetic survey in the Rhenian Palatinate (published only after his retirement, Neumayer, 1905). His former tutor Lamont had suggested to gain experience at home with the new instruments Neumayer had bought for his planned observatory in Australia (see above). With the same instruments he conducted observations at nine sites in Northern Germany that were the basis for his first magnetic chart of Central Europe. He published the results in the "Hydrographische Mitteilungen" (1873). This journal was founded by Neumayer and after 1875 continued as "Annalen der Hydrographie und Maritimen Meteorologie". Later, in Australia, Neumayer carried out regular observations of the geomagnetic elements at the Flagstaff Observatory between 1858 and 1864 and also made a magnetic survey of the complete British colony of Victoria (Neumayer, 1867a, 1869). During these studies he found also small, but regular geomagnetic variations that were apparently connected with the phase of the moon (Neumayer, 1867b). In addition he performed regular hydrographic and meteorological observations at the coast. Before Neumayer returned to Europe, he was asked by Edward Sabine (1788-1883), President of the Royal Society in London, to conduct a magnetic survey in and around the Ross Observatory in Hobarton (Tasmania). Neumayer's report (in English) was never published. He gave, however, a detailed description of this project in Australian pioneering times in a special volume of the "Meteorologische Zeitschrift" (Neumayer, 1906) that was published on the occasion of the 40th anniversary of Julius Hann's (1839-1921) editorship. At the Deutscher Geographentag (the German Geographic Day) in Vienna, 1891, Neumayer explained in detail the methodological aspect of magnetic surveys and their significance (Neumayer, 1891). He emphasized in this presentation the necessity to set up measuring stations at small mean distances in order to resolve local magnetic deviations from the mean field, which he correctly attributed to geological features. He compared the mean distances used in different countries with his own measurements in Germany and Australia, and suggested to use distances from 40 down to $12 \mathrm{~km}$ for an increasing accuracy. Neumayer was backed up by Karl Schering (1854-1925), another influential German geomagnetician (see following sections), who wrote in his review article (Schering, 1894, p. 15, written in 1892):

"Eine sich über ganz Deutschland erstreckende magnetische Aufnahme, welche in fast allen Ländern schon ausgeführt wurde, ist noch eine Aufgabe der Zukunft. Hierin hat Deutschland seine Führerrolle verloren, welche es auf dem Gebiete der erdmagnetischen Forschung zu den Zeiten von Gauß und Weber unbestritten einnahm." ("A magnetic survey over whole Germany which was performed already in almost all countries, is still a task for the future. In this field Germany has lost its leading role that it held in geomagnetic research since the times of Gauß and Weber.")

\section{Neumayer and German naval observatories}

After his return to Germany in October 1864, Neumayer worked as a private scientist, mainly evaluating the results obtained in Australia, and regularly lectured at scientific symposia. In addition, he tried in vain to arrange an expedition to the Antarctic, but was more successful with his suggestions to establish a central German institute for hydrography, meteorology and maritime science. In $1871 \mathrm{Neu}-$ mayer went to Berlin to follow up this plan. In the mean time he had become an important figure in Germany's scientific life, and had earned the title "Dr. honoris causa" (honorary doctor) from the University of München (Priesner, 1999). He lectured in Berlin at the Gesellschaft für Erdkunde (the Society of Earth Science) on the disturbance of the compass in iron ships (Sitzungsbericht, 1872). In the middle of the 19th century, wooden ships had given place to iron merchant ships, and soon afterwards the Navy started to 
build armored vessels. British scientists, such as Peter Barlow (1776-1862), Archibald Smith (1813-1872) and George B. Airy (1801-1892) had already treated the deviation of the compass (Meldau, 1909). With the growth of the German merchant fleet and the increasing maritime interest of the German Empire, this problem emerged in Berlin, too. Albrecht von Stosch (1818-1896), Head of the Admiralty who was responsible for the Imperial Navy, became interested in Neumayer and engaged him in 1872 as "Hydrograph der Admiralität" (hydrographer of the admiralty). Neumayer's wide scientific interests in geomagnetism and in solar-terrestrial relationships paved the way to this influential position. Wilhelm Foerster (1832-1921), the Director of the Astronomical Observatory in Berlin, and very influential as one of the organizers of scientific life in the German capital, described in his autobiography (Foerster, 1911) how effectively he intervened for Neumayer with Stosch.

In his position as naval hydrographer Neumayer helped to establish the "Kaiserliche Erdmagnetische Observatorium" (the Imperial geomagnetic observatory) in Wilhelmshaven (later named "Marineobservatorium Wilhelmshaven"). Building started in 1874, but it took four years to complete the premises (Fig. 2). Neumayer regarded this place as most suitable for magnetic measurements. On his proposal, Carl Börgen (1843-1901), previously assistant to Karl Christian Bruhns (1830-1881) at the Leipzig Astronomical Observatory became head of the institute in 1874. A citation from a letter to Neumayer shows how strongly Börgen was obliged to him (Börgen, 1873/84):

"Ich weiss, und es ist eine große Freude für mich, dass ich Ihre Freundschaft mir erworben habe, und kann Ihnen meinem Dank dafür wohl nicht besser abtragen als [...] Ihnen so viel in meinen Kräften steht, beizustehen in der Erstrebung der Ziele, die Sie sich gesetzt haben." ("I know, and it is a great pleasure for me, that I have acquired your friendship, and I can best express my gratitude to you by supporting the targets you have set as much as I can.”)

Neumayer and several other German geoscientists continued to press also for a civil central German maritime institute, and the German civil merchant fleet supported them. Already in 1868 the German mathematician and natural scientist Wilhelm von Freeden (1822-1894) had founded such an institute from his own money and with the help of 28 influential ship owners from the Chambers of Commerce of Hamburg and Bremen (Ehlers et al., 1993). This "Norddeutsche Seewarte" (North German maritime institute) in Hamburg was transformed 1875 by state law into a national German institution. The German geologist and mineralogist Otto Vogler (1822-1897) coined the name "Deutsche Seewarte" (German Naval Observatory, see Fig. 3) and Neumayer, as a great and continuing advocate of such an institution became its first Director on 13 January 1876 . He remained in this position for 27 years, established an effective internal structure of this

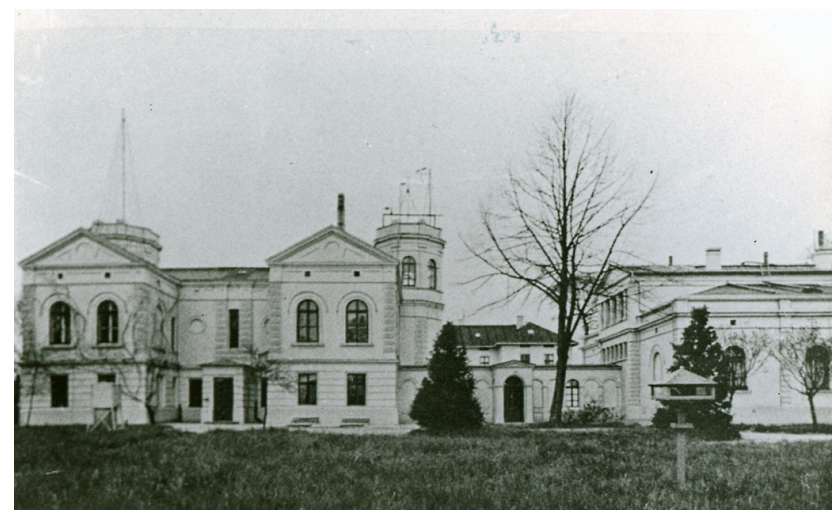

Figure 2. "Marineobservatorium Wilhelmshaven", 1928. The observatory constructed in 1878 was in operation until World War II, when it was heavily damaged by bombs. It was partly rebuild and some parts of the buildings are still in use for other purposes (photograph from Stadtarchiv Wilhelmshaven).

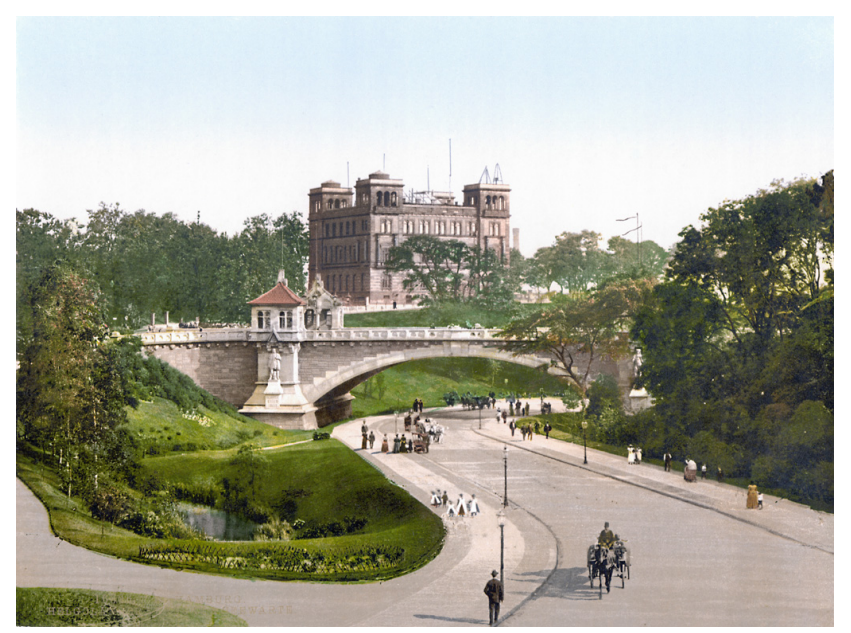

Figure 3. "Deutsche Seewarte" in Hamburg, photograph taken between 1890 and 1905. The building overlooking the harbour in Hamburg was destroyed in World War II (reproduced from WIKIMEDIA COMMONS, http://commons.wikimedia.org).

institution and assured a successful and highly esteemed performance. In the first issue of the subsequently founded periodical "Aus dem Archiv der Deutschen Seewarte" (1878) the structure, the personnel, the buildings, and the instruments are described in detail.

The positioning of a compass on board a vessel and its compensation was the duty of Section II of the "Deutsche Seewarte". It had also to promote the theory of deviation and to propose improvements for technology and industry. Neumayer himself improved and constructed several magnetic instruments, among them a "Deviationsmodell". It was a wooden model ship with a compass on which different iron part could be mounted in order to observe their influence on the bearing, and small magnets for the compensation (Aus 
d. Archiv Dt. Seewarte, 1878, p. 90-91). The new buildings of the "Deutsche Seewarte" completed in 1881, included a "magnetic pavilion", a special building constructed according to Neumayer's plans where the magnetic properties of different iron and steel objects could be studied.

Regular observation of the magnetic elements were not planned by the "Deutsche Seewarte", although instruments like Lamont's great magnetic theodolite, an instrument to measure intensity after Meyerstein, and different inclinometers were available. After measurements in early years, the electromagnetic noise of the growing city soon brought this to an end. Instead of the "Deutsche Seewarte" in Hamburg, the "Marineobservatorium Wilhelmshaven" took over this task until 1936. The "Deutsche Seewarte" (for a brief history in English, see Good, 1998) remained the most important center for nautical affairs in Germany until the end of World War II (later it was similarly successfully continued as "Deutsches Hydrographisches Institut"). Well-known meteorologists worked at this institution, like Wladimir Köppen (1846-1940), Alfred Wegener (1880-1930), and Johannes Georgi (1888-1972).

\section{Geomagnetic investigations during the First Polar Year}

The First Polar Year 1882/1883, inspired by the Austrian Naval Officer and explorer Carl Weyprecht (1838-1881; see Krause, 2008), was one of the first great international scientific co-operations (Lüdecke, 2004). 700 scientists from eleven nations participated in this enterprise. One of the main organizer was Neumayer, at that time President of the International Polar Commission. The organization was somewhat hampered by diplomatic complications in Europe at that time (a detailed survey about the development of the German participation describing also the delicate political issues involved, is given by Krause, 2007). A most recent account of the history of the Polar Years has been written by Barr and Lüdecke (2010).

A survey of the letters, drafts and other papers (Nachlass Neumayer, undated) connected with the "First Polar Year" including also papers from Potsdam (a) and Göttingen (b) shows the extent of the organizational work carried out by Neumayer and his staff at the "Deutsche Seewarte":

a. At the Astrophysical Observatory, Potsdam, Hermann Carl Vogel (1841-1907) was especially interested in spectroscopic studies of aurora. The yellow-green line $(557.7 \mathrm{~nm})$, which could not be identified with any terrestrial substance at that time, posed a most exciting puzzle. The causes and physical processes of aurora were very poorly understood at that time. It was only known that the processes were influenced by the Sun and that electric discharges were involved in some way. Neumayer had discovered already in 1859 in Melbourne that northern and southern auroras appeared simultane- ously (Neumayer, 1901a, p. 216), and had sketched a southern polar oval from existing aurora observations (Neumayer, 1901a, p. 264f). Since Earth currents had been observed together with auroras, such measurements were envisaged as well. The physicist Gustav Robert Kirchhoff (1824-1887) from Berlin presented a comprehensive introduction to these measurements. However, the results of the earth current and auroral observations were disappointing, even a failure, because they did not yield any conclusive evidence.

b. It was evident that the "Sternwarte" (the astronomical observatory) in Göttingen (first Director Carl Friedrich Gauß, starting 1807), headed by Ernst Schering (18331897) and by his younger brother Karl, should participate in the full program of the First Polar Year. The ministry in Berlin, however, treated this famous research institute and the whole university in a very niggardly fashion. The curator of the university, Adolf von Warnstedt (1813-1897) who was left in office by the Prussian government following Prussia's annexation of Hannover in 1866, complained bitterly (von Selle, 1937). Following Neumayer's intervention, and taking into account Göttingen's famous tradition, Berlin voted funds for the enlargement of the "Sternwarte", as shown by E. Schering's letters and by Neumayer's draft letters (E. and K. Schering, 1909; Wiederkehr, 2001).

The two German stations were located at the Kingua Fjord in the Cumberland Sound on Baffin Island $\left(67^{\circ} 15^{\prime} \mathrm{N}\right.$, $67^{\circ} 40^{\prime} \mathrm{W}$ ) and at the Royal Bay on South Georgia in the South Atlantic $\left(54^{\circ} 31^{\prime} \mathrm{N}, 30^{\circ} 24^{\prime} \mathrm{W}\right)$. For the selection of the stations not only geomagnetic aspects were important, however a strong argument for South Georgia was the unanimous requirement of the German Polar Commission for simultaneous geomagnetic observations in both hemispheres. For the northern hemisphere station, first a location on the west coast of Greenland was favored, because Germany had already experience there from an earlier expedition. This plan had to be abandoned however, because of budget restrictions and due to a better accessibility of the Kingua Fjord (Neumayer and Börgen, 1886a). The observations commenced at both stations in the first days of September 1882 and lasted for about one year.

As the "Marineobservatorium Wilhelmshaven" (see above) was equipped with photographically recording magnetometers, the first in Germany, the staff could extensively participate in this international programme (Schröder and Wiederkehr, 2000). The German Polar Commission entrusted Börgen with processing the magnetic records of the German stations (Letter by Börgen, 1873/84). All the results and recordings were published in two large volumes (Neumayer and Börgen, 1886a, b) including descriptions of the observatories, the used instruments and the applied scientific methods. From the total 1260 pages of both volumes, 940 pages are devoted to magnetic observations (including earth 


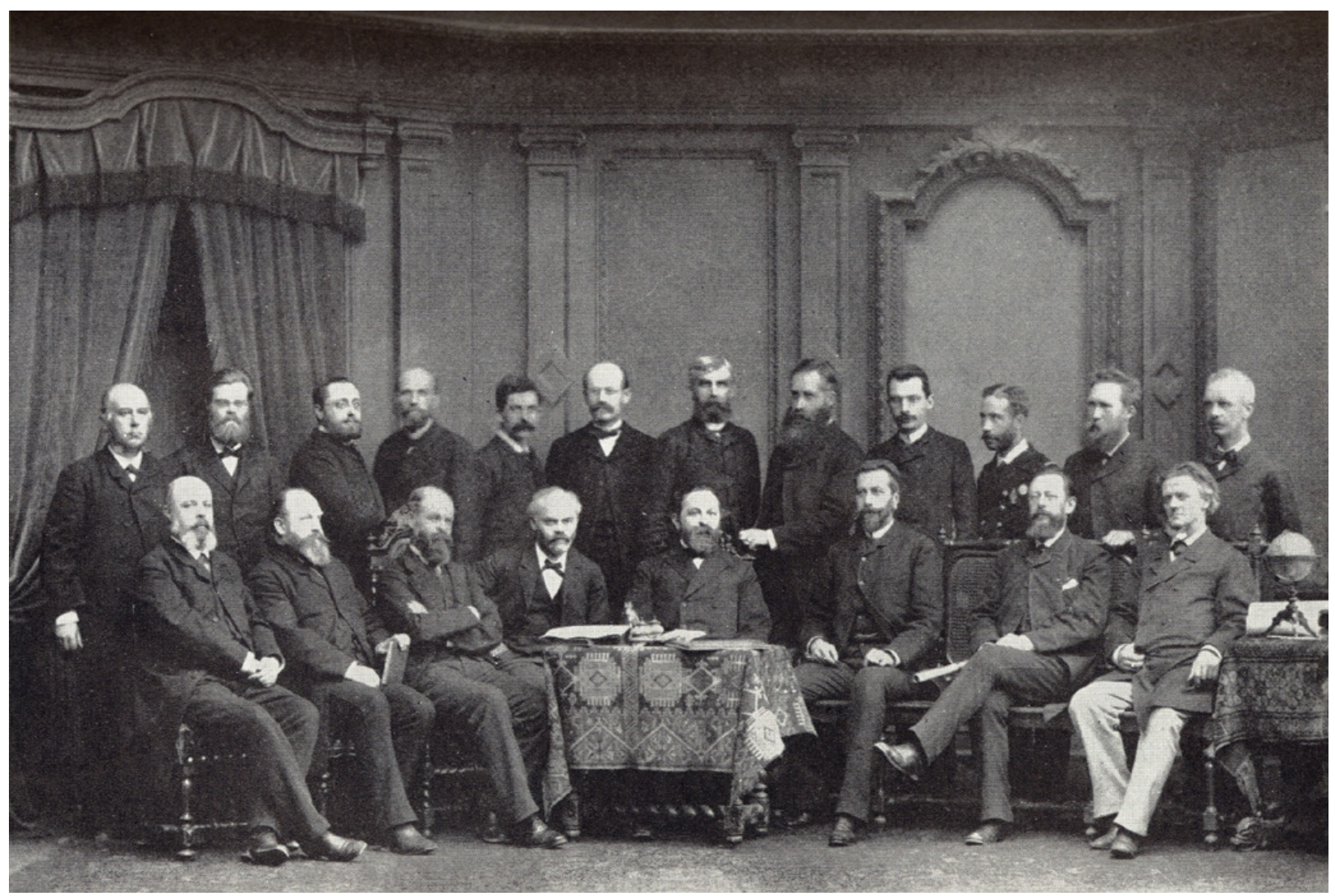

Figure 4. Members of the 4. International Polar Commission at the Congress in Vienna, 1884. The photograph shows several scientists mentioned in the text: G. Neumayer (first row, at right), G. H. Wilczek (first row, third from right), H. Wild (first row, fourth from right), and C. Börgen (second row, fifth from left), (fom Heathcote and Armitage, 1959, copy provided by K. R. Wood, NOAA R/PMEL, Seattle).

currents and aurora, see above); this indicates the importance of the magnetic measurements. The volumes included also the magnetic data from the observatories of Breslau (now Wroclaw, Poland), Göttingen and Wilhelmshaven for reference and comparison. The books do not contain any analysis or interpretation of the data; these were published subsequently in different scientific journals and on scientific meetings. Börgen himself presented an overview of the results and their interpretation at the Chicago World Meteorological Congress in 1893 (Börgen, 1893). Max Eschenhagen (18581901), from the "Marineobservatorium", reported in 1887 at the 7th Deutschen Geographentag (the German Geographic Day) in Karlsruhe, some results of the geomagnetic observations (Eschenhagen, 1887). In his report he focused on the problem of establishing a mean diurnal variation of the magnetic elements for the different stations involved in the measurements, and discussed the problem of separating disturbed days from quite days. He also clearly stated that the regularly applied recording interval of five minutes was too long for a thorough study of disturbances.
The "Marineobservatorium Wilhelmshaven" at that time almost fulfilled the role of a central German magnetic institute in addition to its other tasks in meteorology, hydrology and time service. The newly founded geomagnetic observatory at Potsdam, headed since 1889 by Eschenhagen, took over this role somewhat later (Voppel, 1974).

Finally, it was Neumayer who made it possible that the fourth and final Conference of the International Polar Commission could take place in Vienna (see Fig. 4). In a letter to the President of the Commission, Neumayer's successor Heinrich Wild (1833-1902) in St. Petersburg, he wrote (Nachlass Neumayer, undated):

"Als der Ort der Zusammenkunft erscheint mir Wien sehr passend gewählt werden zu können, da wir dadurch die Verehrung und Dankbarkeit, die wir dem edlen Grafen Wilczek und den Mühen unseres Kollegen Weyprecht schulden, einen beredten Ausdruck geben können". ("As site of the meeting I find Vienna a very good choice, as by adopting it we can express the honor and appreciation we owe to the noble Graf Wilczek and to the efforts of our colleague Weyprecht"), (about Wilczek and Weyprecht, see Berger and Besser, 2008). 


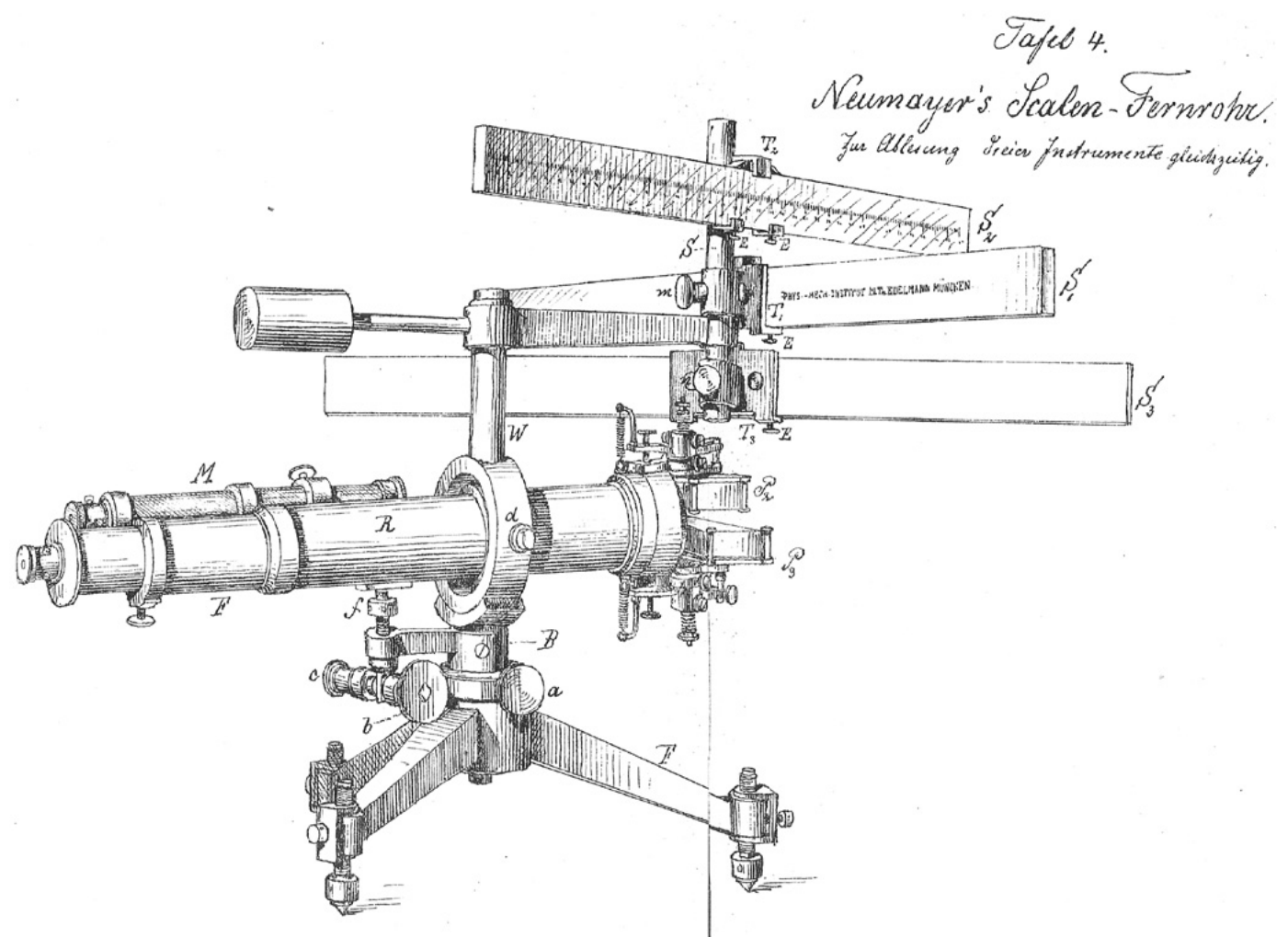

Figure 5. Example of an improvement of a geomagnetic instrument introduced by Neumayer and used during the Polar Year 1882/83. The caption says: Neumayer's scale telescope - for reading simultaneously from three instruments (Edelmann, 1882).

Wild answered in a letter dated 8 November 1883 (Nachlass Neumayer, undated):

“... ich danke Ihnen sehr, dass Sie [...] durch einen bestimmten Vorschlag, auf den ich bis dahin Seitens der Mitglieder der Commission vergeblich wartete, die Initiative ergriffen haben." ("...I thank you very much for the definite proposal for which I had previously waited in vain from the other members of the Commission and to which you took the initiative.")

Neumayer made a further contribution to successful polar research in the field of the construction of instruments. During the sensational drift voyage of the Norwegian Fridtjof Nansen with the ship "Fram", Sigurd Scott-Hansen (18681937, Naval Lieutenant, was in charge of astronomical and meteorological observations onboard "Fram") used in 1893 1896 magnetic instruments manufactured by Carl Bamberg according to construction details given by Neumayer and these proved to be very reliable (Schering, 1905). Bamberg (1847-1892), the son of a watchmaker, founded 1871 in Berlin the well-known company ASKANIA, manufacturer of precision scientific instruments. Some of the instruments for the Polar Year expeditions (Fig. 5) had been fabricated by the prestigious Bavarian precision engineer Max T. Edelmann (Edelmann, 1882).
Roald Amundsen (the first to reach the South Pole in 1911) expressed in his book "Die Nordwest-Passage" (The Northwest Passage, Amundsen, 1907) Neumayer's competence in problems of polar research and geomagnetism among many contemporaneous scientists. Amundsen asked for Neumayer's advice and support before starting his voyage in the Gjøa. He wanted to reach the North magnetic pole and determine its precise position. Amundsen became acquainted with the most recent magnetic instruments and measuring methods at the "Deutsche Seewarte" and as proposed by Neumayer, also visited Börgen in Wilhelmshaven and Adolf Schmidt (see below) in Potsdam (Amundsen, 1907).

5 New computation of the constants and modification of the Gaussian theory by Neumayer, Schmidt and others

Neumayer treated theoretical aspects of geomagnetism as well. He and the high-school professor Heinrich Petersen (1815-1890) carried out a new determination of the 24 Gaussian constants of the spherical functions in order to fit them to the actual magnetic field of the Earth (unpublished, but the results are discussed and presented in Neumayer's explanations of the charts in "Bergaus' Physikalischer 
Atlas", see next section). Erman and Petersen (1874) had computed the constants for the epoch 1829.0 following exactly the Gaussian method, but taking into account the observational results collected during Georg Adolf Erman's (1806-1877) expedition around the Earth in 1828-1830. Neumayer used a much more extensive data set, including data gained during the expeditions of the German corvette "Gazelle" (1874-1876) and the British "Challenger Expedition" (1872-1876), and especially those from the First Polar Year. All values were transformed into absolute units, reduced to the epoch 1885.0 and, based on them, charts were constructed for "Berghaus' Physikalischer Atlas". For the computations of the constants, geographical positions were chosen and the geomagnetic elements for this point were calculated using spherical functions with appropriate constants. These results were compared with the observed values and in case of significant deviations recalculated with better adjusted constants in an iterative process. As Neumayer reported at the 8th German Geographic Day in Berlin in 1889 , the agreement was not satisfactory (Neumayer, 1889a). The discussion that followed his lecture showed that the Gaussian theory should be urgently supplemented. Adolf Schmidt (1860-1944) followed this suggestion and took a rather different approach when modifying the Gaussian theory. Because of the sparse material at his disposal, Gauß had supposed geomagnetism to originate entirely from the interior of the Earth and had neglected any exterior source, in spite of the fact that he accepted the possible existence of such a source; even if it had to be weak. He also mentioned the possibility of electric currents in the atmosphere. Gauß supposed a potential and carried out the computations in a simplified method (Gauß, 1839). The confirmation of his method was the coincidence of the theoretical and the measured values that he found acceptable. In his very detailed Encyclopedia article on "Erdmagnetismus" (geomagnetism) Schmidt (1906/25) wrote on pages 365/366:

"Er [Gauß] zeigte aber auch, wie beim Verzicht auf diese Annahmen zu verfahren sei, und fügte eine Reihe weiterer bedeutsamer programmatischer Darlegungen über die künftige Ausgestaltung der Theorie und ihre Anwendung auf die verschiedenen Erscheinungen, insbesondere die Variationen, hinzu." ("He [Gauß] has also shown how to proceed if this supposition is not accepted and added a series of important programmatic considerations about the future form of the theory and about its application to different phenomena, first of all variations.")

Interior and exterior sources of geomagnetism can therefore be separated by the Gauß method. In his fundamental paper Schmidt (1889) determined every component independently and also considered the flattening of the Earth. Numerical computations were presented in subsequent papers - based on Neumayer's data - and resulted in the statement that a small part of the geomagnetic field is potential-free and accordingly its source must be some electric current flowing in the terrestrial atmosphere (Schmidt, 1895).

In his book "Auf zum Südpol!" containing autobiographical elements, Neumayer (1901a, p. 417f) supposed that it was he who incited the then high-school professor in Gotha, Adolf Schmidt, to devote all his efforts to the study of geomagnetism. As soon as the position of the head of the Potsdam Geomagnetic Observatory became vacant after Eschenhagen's death (1901), he intervened without reservation on behalf of his friend. In a letter to Wilhelm von Bezold (1837-1907, Director of the Meteorological Institute of the University of Berlin) he wrote (Neumayer, 1901b):

"Bei [der] [...] besonderen Begabung [Eschenhagens] für die Construktion und Untersuchung von magnetischen Apparaten dürfte in der That ein entsprechender Ersatz nicht so schnell zu beschaffen sein. Von den beiden Gelehrten, die Sie für die durch den Tod Eschenhagens erledigten Stelle ins Auge fassten, verdient meines Erachtens Herr Prof. Schmidt in erster Linie eine Berücksichtigung, da seine hohe Begabung und seine Leistungen auf dem theoretischen Gebiet des Erdmagnetismus ihm ein gewisses Anrecht erworben haben." ("Regarding [...] the special ability [of Eschenhagen] in the construction and study of geomagnetic instruments, it will be not easy to find quickly a satisfactory substitute. From the two scientists whom you considered to fill the vacant position due to Eschenhagen's death, I find that Professor Schmidt merits special attention as his high ability in the theoretical field of geomagnetism earns him a certain right to it.")

Schmidt assumed this position in 1902 and he proved to be an excellent practitioner and constructor of geomagnetic instruments. His field balance, which is in use even today, should be especially mentioned. Schmidt soon belonged to the group of leading geomagneticians of the first half of the 20th century.

Schmidt applied functions of the sixth order in his numerical computations (48 terms). The mathematician and astronomer Hermann Fritsche (1839-1913) proceeded even further; he continued the series up to terms of the seventh order and obtained correspondingly 63 terms (Fritsche, 1897). The basis for Fritsche's computations was again the Neumayer chart series for epoch 1885.0. John Couch Adams (1819-1892, Professor in Cambridge, famous as discoverer of Neptune) computed the constants for the epoch 1880.0, too (posthumous publication, see Schmidt 1906/25, p. 368/369). The coefficients obtained by NeumayerPetersen, Fritsche, Adams and Schmidt coincide surprisingly well in the first, most important terms, although Adams and Neumayer-Petersen based their computations on independent data collections and secular reductions. A better coincidence of the observed values with those computed backwards, however, could not be reached, as geomagnetism is after all a complex phenomenon. 


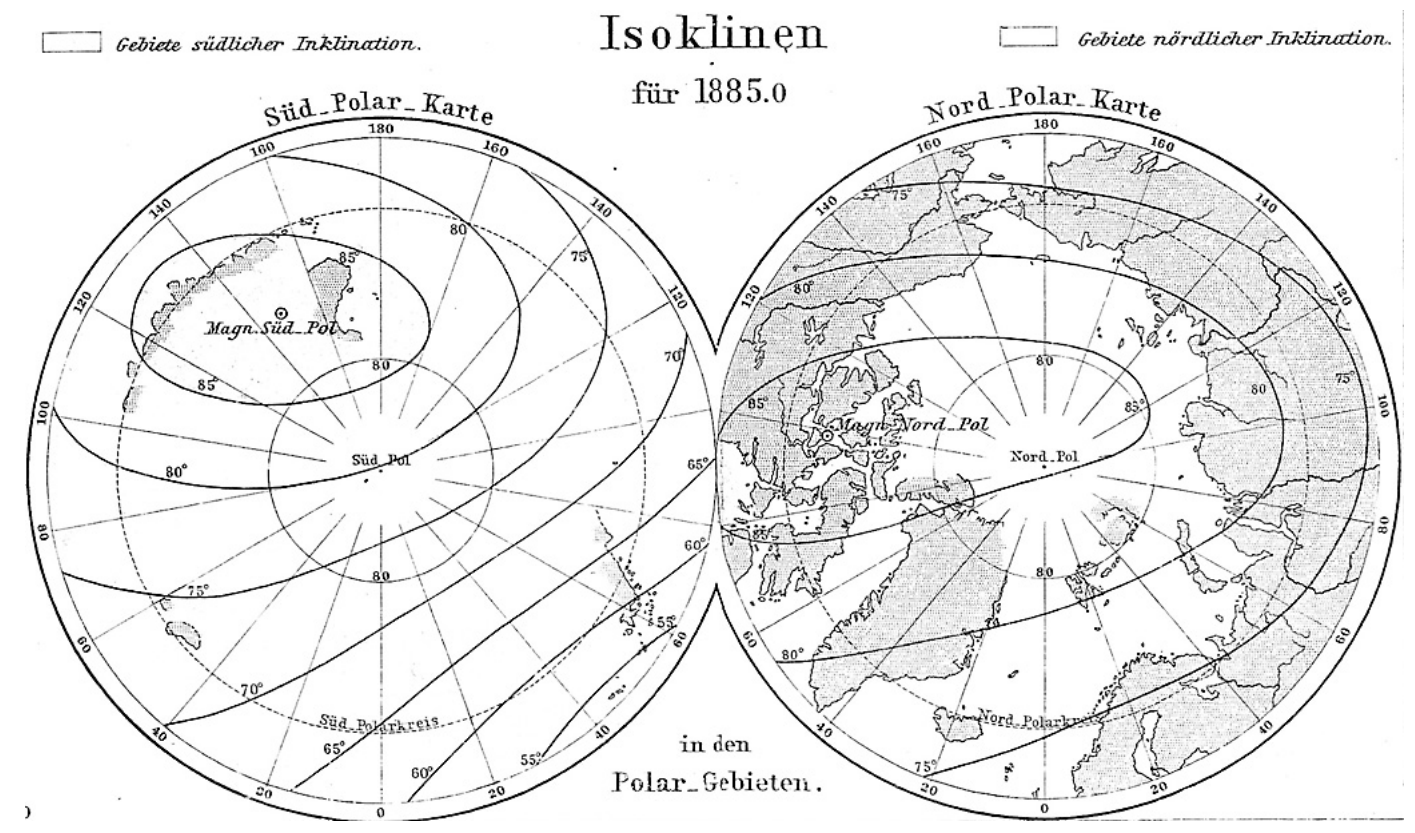

Figure 6. Supplementary chart of main Chart no. 41 of "Berghaus' Physikalischer Atlas" (Abt. 4), showing the isoclines over the polar regions. To supplement the outlines of the Antarctic continent and to add magnetic stations there was one of Neumayer's great concerns.

With regard to the physical causes of geomagnetism and the exact processes responsible for variations, everybody fumbled in the dark in Neumayer's time. Some light came with work of the German-born British physicist Arthur Schuster (1851-1934) on the daily variations (Schuster and Lamb, 1889). Inspired by an article in the Encyclopedia Britannica written by the Scottish physicist Balfour Stewart (1828-1887), he was able to explain these phenomena for the first time by his dynamo theory in which he postulated induced currents in the atmosphere and in the Earth's body (Good, 1988).

\section{Geomagnetic charts}

Neumayer's geomagnetic charts, published as Section IV of "Heinrich Berghaus' Physikalischer Atlas" (1891), should be discussed in more detail. The Atlas of Geomagnetism contains five colored main charts and twenty supplementary ones. The main charts refer to the epoch 1885.0 and represent the (1) isogonals, (2) magnetic meridian curves, (3) isoclines, (4) isodynamic lines of equal horizontal intensity, (see Fig. 6), and (5) changes of the magnetic declination.

The larger charts use the Mercator projection; the polar regions are represented in polar projection as supplementary charts. The twenty supplementary charts include historic ones, e.g. by Hansteen, Sabine, Gauß and Weber. Neumayer paid special attention to the secular variation as he considered it to be the key for future acceptable theories. The fifth main chart represents the change of the magnetic declination between 1600 and 1858, and four supplementary charts give isogonals for different centuries. The first main chart is accompanied by a supplementary chart representing the secular change of the declination between 1870 and 1890. In an introduction of 17 pages Neumayer described the sources of his data and the methods of interpolation. He mentioned the unsatisfactory coincidence of the values computed with the Gaussian constants and gave a survey of the state of art of the research in his time.

In the last years of his life Neumayer published magnetic charts representing the situation around 1900; a chart of the secular change in minutes between 1890 and 1900 is also included (Schering, 1905). Louis Agricola Bauer (1865-1932) included these charts in his US Magnetic Declination Tables and Isogonic Charts for 1902 (Bauer, 1902), and Neumayer prepared also a cartographic table for Bauer's journal "Terrestrial Magnetism and Atmospheric Electricity". Bauer was an American astronomer and well-known geomagnetician, and the first Director of the Department of Terrestrial Magnetism of the Carnegie Institution in Washington D.C.

Karl Schering surveyed all new developments in the field of geomagnetism in six consecutive handbook articles (Schering, 1889, 1891, 1894, 1897, 1900, 1905). In his third article of this series (1894) he wrote (p. 16):

"Herr Neumayer ist unermüdlich thätig, das Interesse an erdmagnetischen Forschungen in weiten Kreisen zu wecken und rege zu halten" ("Mr. Neumayer has been untiringly active to awaken interest of geomagnetic research in a wide community and to maintain interest.") 
Neumayer helped Schering considerably with his wide knowledge of the literature (Letter to H. Wagner, Neumayer, 1889b):

"Herr Professor Karl Schering hatte mir schon vor längerer Zeit mitgeteilt, dass er für das Jahrbuch einen Artikel über magnetische Forschungen zu verfassen hatte. Und ersuchte mich um einige Materialien, die ich ihm zugehen ließ. Hoffentlich wird dieser Überblick dazu beitragen, dass man nun auch in Deutschland mit neuem [...] Interesse diesen lange recht vernachlässigten Zweig des menschlichen Wissens verfolgt." ("Professor Karl Schering informed me already some time ago that he had drafted a paper for the Yearbook on geomagnetic research. And asked me for some material which I sent him. Hopefully this survey will contribute that this long neglected field of human knowledge will be followed up with new [...] interest in Germany, too.")

Kretzer (1984) reported that Neumayer regarded his contributions to Berghaus' Atlas as very special and often had to work for it at night.

\section{Summary and conclusion}

In this paper we treated only Neumayer's work with respect to geomagnetism. He was however, similar successful and influential in meteorology, hydrography and marine science in general (Schröder and Wiederkehr, 1992). In the speech at the celebration of Neumayer's 80th birthday, his contributions to geography, gravity surveys, and nautical science, practice and education were emphasized as well (Günther, 1906). There is no doubt that Neumayer and his work was highly esteemed by his contemporaries. The influential positions he gained (as described in the previous sections) as well as many honors he received clearly prove this (e.g. Köppen, 1909). One of the latest honors was his knighting (Georg Balthasar Ritter von Neumayer) by the King of Bavaria in 1900 (Kretzer, 1984).

It is however, very difficult to separate Neumayer's significance in geomagnetism from his significance and influence in the other areas mentioned above. His contributions to geomagnetic surveys were an important step in establishing geomagnetism as a world- wide phenomenon. His developments and improvements in instrumentation were important and long lasting until digital recording became available in the second half of the 20th century. Similarly, his contribution to the modification of the Gaussian theory was an important step towards modern geomagnetic reference models. The most lasting geomagnetic work of Neumayer was probably the preparation of the geomagnetic charts in "Berghaus' Physikalischer Atlas", their thorough explanation and the careful compilation of its sources. This work was in use for many decades and is still frequently cited in standard textbooks (e.g. Chapman and Bartels, 1951) and reference works (e.g. Runcorn, 1956). It became obsolete only towards the end of the 20th century with the global geomagnetic mapping from space, e.g. with the Danish ØRSTED and the German CHAMP satellites (Lühr et al., 2009).

Another little detail of Neumayer's lasting influence should be mentioned in this context (Günther, 1906, p. IV, Anm. 1):

“... dass Neumayer es war, der das höchst bezeichnende und zweckmäßige [...] Wort 'Geophysik' in der Terminologie heimisch machte, denn bis dahin hat man sich seiner gar nicht bedient." ("... that it was Neumayer, who introduced the most characteristic and useful word "geophysics" in the terminology, since so far one has not used it at all.")

A special sign of Neumayer's recognition was that the first German research station in the Antarctic, established 1981, about one hundred years after the First Polar Year, was named after him.

After a long, scientifically successful and eventful life Neumayer died on 24 May 1909 in Neustadt, Pfalz close to his birthplace. We conclude this review on Neumayer's activity in the development of geomagnetism, as well as his efforts to use it in practice, with some phrases from Wladimir Köppen's obituary (Köppen, 1909, p. 404):

\begin{abstract}
"Diese Zeit des Neuschaffens bot dem ausgesprochen organisatorischen Talent Neumayers das richtige Fahrwasser. Denn er gehörte weniger zu jenen Gelehrten, die in der Stille der Studierstube Gesetze finden oder im Laboratorium durch Experiment und Beobachtungen neue Tatsachen suchen, als zu denen, die nach grossen Gesichtspunkten die wissenschaftliche Arbeit organisieren und durch ihre Schöpfungen sich einen dauernden Platz in der Geschichte der Wissenschaften sichern." ("This time of new activity gave impetus to Neumayer's talent for organisation. Thus, he belonged less to the scientists who find new laws in quiet study or to those who look for new facts in laboratories by experimentation and observation, he belonged rather to those who organize scientific activity according to important points of view and who find a long lasting place by their creations in the history of science.")
\end{abstract}

Acknowledgements. The authors are indebted to R. Krause, Alfred Wegner Institut, Bremerhaven, Germany and G. A. Wood, Center for History of Physics, Colllege Park, MD, USA for valuable hints and suggestions.

The "Georg von Neumayer Stiftung" within the "Pollichia", a natural history association located in Bad Dürkheim (close to Neumayer's birth place) keeps the remembrance of Neumayer alive, supports research in Neumayer's sense and maintains an archive. Neumayer itself was a member of Pollichia since 1865. More information can be found at: http://cms.pollichia.de.

Edited by: V. Schwach

Reviewed by: three anonymous referees 


\section{References}

Amundsen, R.: Die Nordwest-Passage, Meine Polfahrt auf der Gjøa 1903-1907, München, Germany, 1907.

Aus dem Archiv der Deutschen Seewarte, 1. Jahrg., Hamburg, 1878 (no author specified).

Barr, S. and Lüdecke, C. (Eds.): The History of the International Polar Years (IPYs), Springer-Verlag, Berlin, Heidelberg, 2010.

Bauer, L. A.: United States Magnetic Declination Tables and Isogonic Charts 1902, Government Printing Office, Washington, available at: http://www.archive.org/stream/ unitedstatesmag01bauegoog/unitedstatesmag01bauegoog_djvu. txt, 1902.

Berger, F. and Besser, B. P.: Carl Weyprecht und Graf Hans Wilczek. Zwei Österreichische Lebensläufe, in: Carl Weyprecht, Seeheld, Polarforscher, Geophysiker, edited by: Berger, F., Besser, B. P., and Krause, R. A., Verlag der Österreichischen Akademie der Wissenschaften, Wien, Austria, 19-54, 2008.

Berghaus' Physikalischer Atlas, Abt. 4: Atlas des Erdmagnetismus, Bearbeitet von G. Neumayer, Perthes, Gotha, Germany, 1891.

Börgen, C.: Brief an Neumayer vom 29. Nov. 1873, in: 84 Briefe von C. Börgen an G. von Neumayer, Bibliothek des Deutsches Museum München, Urkunden- und Handschriften Sammlung, München, Germany, 1873-84.

Börgen, C.: The International Polar Expedition 1882-83, Washington DC, USA, 1893.

Chapman, S. and J. Bartels: Geomagnetism, Vol. 2, Clarendon, Oxford, 1951.

Edelmann, M. T.: Die erdmagnetischen Apparate der PolarExpeditionen im Jahre 1883 aus den Werkstätten von M. Th. Edelmann, Vieweg, Braunschweig, Germany, 1882.

Ehlers, P., Duensing, G., and Heise, G.: Schiffahrt und Meer - 125 Jahre maritime Dienste in Deutschland, Mittler und Sohn, Herford, Germany 1993.

Erman, A. and Petersen, H.: Die Grundlagen der Gaussischen Theorie und die Erscheinungen des Erdmagnetismus im Jahre 1829, Reimer, Berlin, Germany, 1874.

Eschenhagen, M.: Einige Resultate der erdmagnetischen Stationen im System der internationalen Polarforschung, in: Verhandlungen des 7. Deutschen Geographentages zu Karlsruhe, 1887, 141151, Berlin, Germany, 1887.

Foerster, W.: Lebenserinnerungen und Lebenshoffnungen, Reimer, Berlin, Germany, 1911.

Fritsche, H.: Über die Bestimmung der Koeffizienten der Gaussischen allgemeinen Theorie des Erdmagnetismus für das Jahr 1885 und über den Zusammenhang der drei erdmagnetischen Elemente untereinander, St. Petersburg, Russia, 1897.

Gauß, C. F.: Allgemeine Theorie des Erdmagnetismus, in: Resultate aus den Beobachtungen des Magnetischen Vereins im Jahre 1938, Leipzig, Germany, 1839.

Good, G. A.: The study of geomagnetism in the late 19th century, EOS, 69, p. 218, 1988.

Good, G. A.: Deutsche Seewarte, in: Sciences of the Earth, Vol. 1, 168-170, Garland, New York, 1998.

Günther, S.: Festschrift zur Feier des 80. Geburtstags von Georg von Neumayer, Pollichia, Bad Dürkheim, Germany, 1906.

Heathcote, N. and Armitage, A.: The First International Polar Year., in: Annals of the International Geophysical Year, Vol. 1, Pergamon Press, London, 6-105, 1959.
Hydrographische Mitteilungen, edited by: Hydrographischen Bureau der Kaiserlichen Admiralität, Vol. 1., Mittler und Sohn, Berlin, 5-7 and 282-287, 1873 (no author specified).

Köppen, W.: Nachruf für G. von Neumayer, Meteorol. Zeitschr., 23, 403-407, 1909.

Krause, R. A.: Georg von Neumayer (1826-1909) - a pioneer of Antarctic research, in: Proc. of the 1. SCAR Workshop on the History of Antarctic Research, edited by: Lüdecke, C., Munich, Germany, 2005.

Krause, R. A.: Das erste Internationale Polarjahr (IPY) 1882/1883: Die Entwicklung der Beteiligung Deutschlands, Polarforschung, 77(I), 17-36, 2007.

Krause, R. A.: Carl Weypreht (1838-1881) - Initiator der Internationalen Polarforschung, in: Carl Weyprecht, Seeheld, Polarforscher, Geophysiker, edited by: Berger, F., Besser, B. P., and Krause, R. A., 19-54, Verlag der Österreichischen Akademie der Wissenschaften, Wien, Austria, 2008.

Kretzer, H.-J.: Windrose und Südpol. Leben und Werk des großen Pfälzer Wissenschaftlers Georg von Neumayer, Pollichia Sonderheft 4, Bad Dürkheim, Germany, 1884.

Lüdecke, C.: The First International Polar Year (1828-83) - A big science experiment with small science equipment, History of Meteorology, 1.1, 54-63, 2004.

Lühr, H., Korte, M., and Mandea, M.: Recent geomagnetic field and its variations, in: Geomagnetic Field Variations, Springer, Berlin-Göttingen-Heidelberg, 2009.

Meldau, H.: Nautik, in: Encykl. der math. Wissenschaften mit Einschluss ihrer Anwendungen, Bd. 6, Teil 1, 297-369, Leipzig, Germany, 1909.

Nachlass Neumayer: Bibliothek des Bundesamtes für Seeschiffahrt und Hydrographie, Hamburg, Germany, undated.

Neumayer, G.: Discussion of the meteorological and magnetical observations, made at the Flagstaff Observatory, Melbourne during the years 1858-1863, Mannheim, Germany, 1867a.

Neumayer, G.: On the lunar-diurnal variation of the magnetic declination with special regard to the Moon's declination, Phil. Trans. Royal. Soc. London, 157, 503-511, $1867 \mathrm{~b}$.

Neumayer, G.: Results of the magnetic survey of the colony of Victoria executed during the years 1858-1864, Schneider, Mannheim, Germany, 1869.

Neumayer, G.: Über das gegenwärtig vorliegende Material für erdund weltmagnetische Forschung, in: Verh. des Achten Deutschen Geographentages zu Berlin 1889, Berlin, Germany, 1889a.

Neumayer, G.: Brief an Hermann Wagner vom 24.1.1889, Niedersächsische Staats- und Universitätsbibliothek, Göttingen, Germany, 1889b.

Neumayer, G.: Über die Bedeutung und Ziele erdmagnetischer Landesvermessungen, in: Verhandl. des Neunten Deutschen Geographentages zu Wien 1891, Berlin, Germany, 11-27, 1891.

Neumayer, G.: Auf zum Südpol!, Vita Deutsches Verlagshaus, Berlin, Germany, 1901a.

Neumayer, G.: Brief an W. von Bezold vom 21. Nov. 1901, PfalzMuseum für Naturkunde, Bad Dürkheim, Germany, 1901b.

Neumayer, G.: Eine erdmagnetische Vermessung der bayrischen Rheinpfalz 1855/56, Mitteilungen der Pollichia, Bad Dürkheim, Germany, 1905.

Neumayer, G.: Die geologisch-magnetischen Verhältnisse des einstigen erdmagneti-schen Observatoriums in Hobarton (Thasmanien), in: Meteorolog. Zeitschr., Hann-Band, redig. J. M. Pert- 
ner und G. Hellmann, Vieweg, Braunschweig, Germany, 67-81, 1906.

Neumayer, G. and Börgen, C., (Hrsg): Die Internationale Polarforschung 1882-1883. Die Beobachtungs-Ergebnisse der Deutschen Stationen, Band I, Kingua-Flord, Asher, Berlin, Germany, 1886a.

Neumayer, G. and Börgen, C., (Hrsg): Die Internationale Polarforschung 1882-1883. Die Beobachtungs-Ergebnisse der Deutschen Stationen, Band II, Süd-Georgien, Asher, Berlin, Germany, 1886b.

Priesner, C.: Neumayer, in: Neue Deutsche Biographie, Bd. 9, Duncker und Humblot, Berlin, Germany, 166-168, 1999.

Runcorn, S. K.: The Magnetism of the Earth Body, in: Handbuch der Physik, edited by: Flügge, S., Vol. XLVII (Geophysik I), Springer, Berlin-Göttingen-Heidelberg, 1956.

Schering, K.: Die Entwicklung und der gegenwärtige Standpunkt der erdmagnetischen Forschung in: Geographisches Jahrbuch, 13, Perthes, Gotha, Germany, 171-220, 1889.

Schering, K.: Bericht über die Fortschritte unserer Kenntnis vom Magnetismus der Erde, in: Geographisches Jahrbuch, 15, Perthes, Gotha, Germany, 141-164, 1891.

Schering, K.: Bericht über die Fortschritte unserer Kenntnis vom Magnetismus der Erde (III, 1891-1892) in: Geographisches Jahrbuch, 17, Perthes, Gotha, Germany, 1-40, 1894.

Schering, K.: Magnetismus der Erde (IV, 1893-96) in: Geographisches Jahrbuch, 20, Perthes, Gotha, Germany, 3-36, 1897.

Schering, K.: Bericht über die Fortschritte unserer Kenntnisse vom Magnetismus der Erde (V, 1896-1898), in: Geographisches Jahrbuch, 23, Perthes, Gotha, Germany, 3-62, 1900.

Schering, K.: Bericht über die Fortschritte unserer Kenntnis vom Magnetismus der Erde (VI, 1899-1904), in: Geographisches Jahrbuch, 28, Perthes, Gotha, Germany, 291-372, 1905.

Schering, E. and Schering, K.: Beobachtungen in Gauss' erdmagnetischen Observatorium der kgl. Universität Göttingen während der Polarexpeditionen 1882 und 1883, in: E. Schering, Gesammelte Werke, edited by: Haussner, R. and Schering, K., Bd. 2, Berlin, Germany, 107-144 und 468-470, 1909.
Schmidt, A.: Mathematische Entwicklungen zur allgemeinen Theorie des Erdmagnetis-mus, in: Aus dem Archiv der Deutschen Seewarte, 12. Jg., Nr. 3, 1889.

Schmidt, A.: Mitteilungen über eine neue Berechnung des erdmagnetischen Potentials, in: Abhandlung der mathematischphysikalischen Klasse der kgl. Bayrischen Akademie der Wissensch. Bd. 19, München, Germany, 1895.

Schmidt, A.: Erdmagnetismus (completed 1917), in: Encyklopädie der Math. Wissenschaften, 6. Band, Teil 1, 266-389, Leipzig, Germany, 1906-1925.

Schröder, W. and Wiederkehr, K. H.: Georg von Neumayer (18261909) und die internationale Entwicklung der Geophysik, 1. Teil: Meteorologie, Gesnerus 49, 45-62, 1992.

Schröder, W. and Wiederkehr, K. H.: A history of early recording of geomagnetic variations, J. Atmosph. Solar-Terr, Phys., 62, 323334, 2000.

Schuster, A. and H. Lamb: The diurnal variation of terrestrial magnetism, Phil. Trans. Roy. Soc. London, A, 180, 467-518, 1889.

Sitzungsbericht vom 30. Februar 1872, Zeitschr. der Gesellschaft für Erdkunde zu Berlin, 7, 93-95, 1872 (no author specified).

von Selle, G.: Die Georg-August Universität zu Göttingen, Göttingen, Germany, 1937.

Voppel, D.: Hundert Jahre Erdmagnetischer Dienst in Norddeutschland, in: Festschrift zur 50-jährigen Wiederkehr der Gründung der deutschen Geophysikalischen Gesellschaft, edited by: Birett, H., Helbig, K., Kertz, W., and Schmucker, U., BerlinHeidelberg-New York, 1974.

Wiederkehr, K. H. and Schröder, W.: Georg von Neumayers geophysikalisches Projekt in Australien und Alexander von Humboldt, Gesnerus, 46, 93-115, 1989.

Wiederkehr, K. H.: Das Gauß-Observatorium für Erdmagnetismus und das Erste Polarjahr 1882-1883, in: Gauß-Gesellschaft, Mitteilungen Nr. 38, Göttingen, Germany, 29-47, 2001. 